\title{
Evidence for recycled surface-derived sulfur in Earth's oldest mantle peridotites from southern West Greenland
}

\author{
DR. J. ELIS HOFFMANN ${ }^{1}$, JONATHAN A LEWIS ${ }^{1}$, \\ ESTHER M. SCHWARZENBACH ${ }^{1}$, HARALD STRAUSS ${ }^{2}$, \\ HANS J C VRIJMOED ${ }^{1}$ AND MINIK T ROSING ${ }^{3}$ \\ ${ }^{1}$ Freie Universität Berlin \\ ${ }^{2}$ Westfälische Wilhelms-Universität Münster \\ ${ }^{3}$ University of Copenhagen \\ Presenting Author: jeh@zedat.fu-berlin.de
}

Eoarchean geodynamic processes are not well understood yet and it is debated if modern-style plate tectonics existed. Recently though, trace element geochemistry of Eoarchean supracrustal rocks from the 3.7-3.8 Ga Isua Supracrustal belt (ISB; e.g., [1]) and adjacent $>3.8 \mathrm{Ga}$ mantle peridotites [2] have been inferred to retain evidence for modern-like subduction processes.

Here we investigate the multiple sulfur $\left({ }^{32} \mathrm{~S},{ }^{33} \mathrm{~S},{ }^{34} \mathrm{~S},{ }^{36} \mathrm{~S}\right)$ isotope composition of well-characterized Eoarchean harzburgites and dunites from the area south of the ISB. We determined the sulfur isotope composition of mono- and disulfides of nine peridotite samples. Most samples show small, but significant MIF-S signals, whereas $\delta^{34} \mathrm{~S}$ values range from -0.2 to $+4.9 \%$. This MIF-S signal provides evidence for incorporation of surface-derived sulfur of $>2.4 \mathrm{Ga}$ of age. In addition, Platinum-group-element (PGE) abundances, major and trace element compositions of these peridotites show evidence for variable degrees of melt refertilization [2,3], possibly related to a subduction overprint. Interestingly, the most depleted peridotites show the most positive $\Delta^{33} \mathrm{~S}$ values similar to the range obtained from amphibolites with tholeiitic composition from the ISB [4]. The $\Delta^{33} \mathrm{~S}_{\text {monos }}$ are correlated with parameters indicative for melt refertilization as reflected by strong correlations with e.g., Fo\# in olivine, $\mathrm{Al}_{2} \mathrm{O}_{3}, \mathrm{Pt}$ and $\mathrm{Sc}$ abundances indicative of an overprint with basaltic melts with zero or negative $\Delta^{33} \mathrm{~S}$ values. Such correlations strongly argue for a magmatic rather than a secondary origin of the sulfides. Mineralogical investigations reveal that most sulfides are pentlandite and pyrrhotite, showing exsolution textures, also pointing to a primary magmatic origin.

Overall, these findings are best explained in a subductionrelated context, in which these peridotites may resemble fragmented lenses of mantle wedge that were incorporated into horizontally thickened mafic crust prior to the intrusion of tonalites at ca. $3.8 \mathrm{Ga}$.

${ }^{1}$ Jenner et al. (2009) Chem. Geol., 261, 83-98.

${ }^{2}$ van de Löcht et al. (2020), GCA 280, 1-25.

${ }^{3}$ van de Löcht et al. (2018), Geology 46, 199-202.

${ }^{4}$ Siedenberg et al. (2016), Precamb. Res. 283, 1-12. 